\title{
The epistemic and evidential use of Spanish modal adverbs and verbs of cognitive attitude
}

Suggested citation referring to the original publication:

Folia Linguistica, 46 (2012), 1, S. 133-170

DOI: http://dx.doi.org/10.1515/flin.2012.5

Postprint archived at the Institutional Repository of the Potsdam University in:

Postprints der Universität Potsdam

Philosophische Reihe ; 107

ISSN 1866-8380

http://nbn-resolving.de/urn:nbn:de:kobv:517-opus4-93929 



\title{
The epistemic and evidential use of Spanish modal adverbs and verbs of cognitive attitude ${ }^{1}$
}

\author{
Anja Hennemann \\ University of Potsdam
}

This article deals with Spanish modal adverbs and verbs of cognitive attitude (Capelli 2007) and their epistemic and/or evidential use. The article is based upon the hypothesis that the study of the use of these linguistic devices has to be highly context-sensitive, as it is not always (only) the sentence level that has to be looked at if one wants to find out whether a certain adverb or verb of cognitive attitude is used evidentially or epistemically. In this article, therefore, the context is used to determine which meaning aspects of an element are encoded and which are contributed by the context. The data were retrieved from the daily newspaper El País. Nevertheless, the present study is not a quantitative one, but rather a qualitative study. My corpus analysis indicates that it is not possible to differentiate between the linguistic categories of evidentiality and epistemic modality in every case, although it indeed is possible in the vast majority of cases. In verbs of cognitive attitude, evidentiality and epistemic modality seem to be two interwoven categories, while concerning modal adverbs it is usually possible to separate the categories and to distinguish between the different subtypes of evidentiality such as visual evidence, hearsay and inference.

Keywords: evidentiality, epistemic modality, Spanish modal adverbs, Spanish verbs of cognitive attitude, context sensitivity

\footnotetext{
${ }^{1}$ I would like to thank two anonymous referees for their severe but helpful comments on an earlier draft of this article. I also benefited from comments by Gerda Haßler and Bert Cornillie.
}

Folia Linguistica 46/1 (2012), 133-170.

ISSN 0165-4004, E-ISSN 1614-7308 C C Mouton de Gruyter - Societas Linguistica Europaea DOI $10.1515 /$ FLIN.2O12.5 


\section{Introduction}

Evidentiality is not a linguistic category grammatically inherent in the language system of Contemporary Spanish as it does not have real evidentials as found in Kashaya (Oswalt 1986), Fasu (Foley 1986: 165) and Quechua Wanka (Floyd 1997), for instance. Nevertheless, it can be expressed by lexical and non-grammaticalized or partially grammaticalized means. Wellknown studies such as, for example, Boas (1947), Barnes (1984), Willett (1988), Aikhenvald $(2003,2004)$, in which evidentials are described from a semasiological perspective, were the basis for research in languages that do not possess real evidentials. This means that once we have figured out the meanings of evidentials, we can search for linguistic devices showing the same or similar function(s). Studies by Haßler $(1997,2002,2004,2010)$, Volkmann (1997, 2005), Große (2000), Cornillie (2007, 2010a, 2010b), Cappelli (2007), Simon-Vandenbergen \& Aijmer (2007), Wachtmeister Bermúdez (2004, 2005), Squartini (2001, 2004), Dendale \& Tasmowski (1994) and Reyes $(1996,2002)$ treat evidentiality from an onomasiological perspective. The works "I reckon I know how Leonardo da Vinci must have felt. . .". Epistemicity, evidentiality and English verbs of cognitive attitude (Cappelli 2007) and The semantic field of modal certainty: A corpusbased study of English adverbs (Simon-Vandenbergen \& Aijmer 2007) are two studies that treat verbs of cognitive attitude and adverbs of certainty in epistemic-evidential terms from such an onomasiological perspective. They are of great relevance for the present study.

In contrast to Cappelli, who describes the epistemic and evidential use of British English verbs of cognitive attitude in a very detailed way, SimonVandenbergen \& Aijmer explicitly examine the context-sensitive use of English modal adverbs. In Spanish, verbs of cognitive attitude as well as modal adverbs also represent linguistic devices which are not only used to express the speaker's epistemic stance but also evidentiality. Following Cappelli and Simon-Vandenbergen \& Aijmer, the aim of this study is to determine which verbs of cognitive attitude and which modal adverbs predominantly belong to the linguistic domain of evidentiality, and which ones to epistemic modality in Spanish. Following Cappelli's line of argumentation, for Spanish verbs of cognitive attitude I also expect "that each and every one of the members of the class has its own place within the system, even though contextual constraints can force the single verbs into the 
semantic space of the others" (Cappelli 2007: 301), and that "[n]ot all evidential forms inherently convey epistemic meaning, and not all epistemic expressions bear reference to evidence" (Cappelli 2007: 130). In this study, evidentiality is understood as "a semantic-functional domain having to do with the kinds of 'proof' speakers are able to adduce in order to underpin their statements" (Diewald \& Smirnova 2010: 2). Hence, linguistic elements are used to express evidentiality if they indicate the source of information a speaker uses to underpin his statement (cf. Diewald \& Smirnova 2010: 2). Epistemic modality, in contrast, "has to do with knowledge" (Portner 2009: 2). More precisely, epistemic modality expresses "the evaluation of the chances that a certain hypothetical state of affairs under consideration (or some aspect of it) will occur, is occurring or has occurred in a possible world" (Nuyts 2001: 21). While linguistic elements expressing evidentiality indicate the source of information for a state of affairs, linguistic elements expressing epistemic modality indicate the speaker's attitude towards a certain state of affairs.

In this article the context will be used to determine which meaning aspects of an element are encoded and which meaning aspects are contributed by the context. The adverbs evidentemente 'evidently' and obviamente 'obviously', for example, encode the meaning aspect that something 'is evident/obvious' - that something is visually perceivable. Both adverbs seem to indicate 'what is known from visual evidence'. Evidentemente may also be used if the evidence is inferential in nature, as example (1) indicates. Example (2) contains obviamente with its meaning it is obvious', that is, it conveys the meaning which is encoded. In example (1) the inferential meaning is contributed by the context, while in example (2) the encoded meaning aspect of obviamente is verified by the context: the fact that the boot is broader is visually perceptible:

(1) [...] la Policlínica Tibidabo en Barcelona ofrece pastillas y tratamientos a sus pacientes para dejar de ser gays. . ha reabierto la polémica sobre una opción descartada en 1973, cuando los científicos rechazaron esta inclinación como trastorno psicológico. "Evidentemente, no se puede curar la homosexualidad. Estas terapias suponen mala praxis y están desautorizadas. Causan trastornos depresivos, conductas autodestructivas, ansiedad y pueden derivar en el suicidio", afirma la psicóloga Silvia Morell. (El País, 24 June 2010) 
'[the fact that] Tibidabo hospital in Barcelona offers pills and treatment in order to cure homosexuality has caused controversy about the right of choice, as in 1973, when scientists refused to see this inclination as a psychological disturbance. "Evidently, one cannot cure homosexuality. These therapies are not allowed and cause depressive disturbances, self-destructive behaviour, anxiety and can lead to suicide," affirms psychologist Silvia Morell.'

(2) Una protección que también se ha puesto en la pierna izquierda, a petición del propio Rossi, que tendrá así las mismas sensaciones en ambas piernas. También la bota ha sufrido modificaciones: es obviamente más ancha para garantizar un mejor confort de la pierna y para permitir una mejor inserción de la misma; además, se ha añadido una segunda cremallera, una apertura lateral para facilitar [...]. (El País, 19 July 2010)

'On Rossi's demand, he has put a protection on his left leg as well, so that he has the same feeling in both legs. Also the boot has been modified: obviously, bigger for more convenience and for a better insertion of the leg; furthermore, a second zipper has been added, a lateral opening to help [...]'

As the examples indicate, this highly context-sensitive study will concentrate on data from a daily newspaper because newspapers, such as El País, combine direct quotes that are oral in character as well as the journalist's written consideration of a certain state of affairs. Because of the contextsensitiveness, I will have to go beyond the sentence as "logical [. . .] relations which are expressed within the sentence in one case may indeed be expressed between sentences in other cases" (Simon-Vandenbergen \& Aijmer 2007: 82). However, intonation and paralinguistic devices cannot be considered here due to the text type that is worked with.

The article's main contribution is twofold: it describes the evidential and epistemic meaning aspects of Spanish verbs of cognitive attitude and modal adverbs in particular contexts and it highlights the importance of taking the context into account when analysing the meanings of these linguistic elements. Working with naturally occurring data, this study intends to demonstrate that the context shows which meaning aspects of a particular lexical item are encoded and which ones are contributed.

The overall aim of this study is to contribute to the research field of evidentiality in languages that do not possess real evidentials. 


\section{Theoretical and methodological background}

Reading online-news articles one gets the impression that for interviewed persons as well as for journalists verbs of cognitive attitude and modal adverbs are prominent stylistic devices to indicate the source of information for a state of affairs they are talking about or to express their epistemic attitude. So after having gotten the impression from a pre-research phase that daily newspapers such as El País are a representative information source' - to speak in evidential terms - for analysing the use of verbs of cognitive attitude and modal adverbs, the work with GlossaNet (http://glossa. fltr.ucl.ac.be/) represented a good opportunity to study the epistemic and evidential use of Spanish modal adverbs and verbs of cognitive attitude in a methodological and subtle way. GlossaNet was set up to search for the following linguistic items based on the insights from the pre-research phase as they were found to be the most frequent ones:

- Modal adverbs: aparentemente 'apparently', evidentemente 'evidently', obviamente 'obviously', posiblemente 'possibly', probablemente 'probably', seguramente 'certainly' and supuestamente 'supposedly'.

- Verbs of cognitive attitude: creo 'I believe', pienso 'I think', sé 'I know' and supongo 'I suppose.'

Although between 1 May 2010 and 23 July 2010 I was receiving a remarkable quantity of results via email from GlossaNet, this study does not aim to be a quantitative one. It is a qualitative study where the data are used to verify/refute the theoretical basis. It is, for example, not my intention to show in how many cases of a certain total amount of uses the Spanish adverb evidentemente is used to express inference. Working with other data, different text genres and perhaps working over a longer period of time the results would not be congruent. I only want to show that modal adverbs and verbs of cognitive attitude are used to express evidential values as well as in which cases certain meaning aspects of an element are encoded and in which cases they are contributed by the context.

The article cannot exhaustively deal with the different syntactic positions of the linguistic elements. Nevertheless, the syntactic position at the sentence level will be considered in so far as constructions that introduce a

${ }^{2}$ GlossaNet was set up to search for first-person-singular verbs because "they truly encode the subject's attitude" (Cappelli 2007: 112). 
supposition such as supongo que $[p]$ as well as constructions where the verb is to be found at the right periphery of the proposition such as $[p]$, supongo are to be considered here. The same holds for the use of modal adverbs.

Verbs of cognitive attitude were extensively studied by, for instance, Cappelli (2007) and Nuyts (2001). Cappelli (2007: 301) describes them as "one of the means to give voice to one's own epistemic-evidential stance". This means that Cappelli recognises a relation of dependency between the linguistic categories evidentiality and epistemic modality, whereas Squartini (2004) tried to disentangle this relationship in the Romance Languages. Cappelli also points out that even though "[e]pistemic evaluation changes according to the evaluation of the evidence on which it is based [and] we can conclude that evidentiality and epistemicity are intimately interwoven semantic domains that are sometimes very difficult to split [. . .]" (Cappelli 2007: 130), epistemic modality and evidentiality are distinct categories (Cappelli 2007: 130). According to Nuyts the two linguistic domains overlap in every "epistemic use of the mental state predicates" (Nuyts 2001: 108). He explains that every speaker using a verb of cognitive attitude - in his terms 'epistemic predicate' - relies on the information source he has for the state of affairs (Nuyts 2001: 111). But the question is whether this reliance on the information source is inherent in the semantics of a particular verb or not, or whether it can be verified with the help of the context.

Simon-Vandenbergen \& Aijmer (2007) study the epistemic-evidential use of British English modal adverbs, working with the notion of procedural meaning because they assume that "adverbs, at least in some of their senses, have procedural rather than conceptual meaning" (SimonVandenbergen \& Aijmer 2007: 52):

it is possible that [adverbs of certainty] have both 'contentful' and procedural meaning. An adverb has a specific evidential or epistemic modal meaning. We will refer to this as the conceptual meaning of the adverbs and distinguish it from the procedural meaning. For example, certainly is contentful in that it means epistemic certainty and procedural when looked upon from the perspective of indexing the speaker's or writer's stance to the text or one of the participants. (Simon-Vandenbergen \& Aijmer 2007: 54) ${ }^{3}$

\footnotetext{
${ }^{3}$ In addition, Cornillie explains that "[...] a satisfactory account of modal adverbs not only examines their semantic (and pragmatic) meaning, but also deals with their interactional or procedural meaning" (Cornillie 2010a: 300).
} 
But for evidently, for instance, they explain: "Evidently seems to have two senses, 'in a way that is easy to see or understand' and 'according to what we know, especially from hearsay'" (Simon-Vandenbergen \& Aijmer 2007: 161). Considering this adverb, however, which meaning of evidently would be contentful and which procedural? As this does not seem easy to answer, I would rather distinguish between meaning aspects that are encoded and others that are contributed by the context. The Spanish counterpart evidentemente is used to express both visual evidence (evidentemente ${ }_{[v i s]}$ ) and inference (evidentemente ${ }_{[\mathrm{inf}]}$ ):

(3) [...] menos que hace un año, 20.079 bolivianos menos o 11.713 argentinos menos. Pero es equívoco afirmar que todas estas personas "regresaron a casa". Lo que nos dicen los datos del padrón es que se ha producido un cambio de ciclo $y$, evidentemente ${ }_{[\text {[iff] }}$ llegan muchos menos extranjeros. (El País, 9 May 2010)

'[...] less than a year ago, 20,079 Bolivians less or 11,713 Argentinians less. But it is wrong to say that all these people "went back home." What the census data show us is that there has been a cycle change and, evidently, fewer foreigners are coming.'

(4) ¿Fueron los neumáticos of fue Lorenzo el culpable de la caída? "Estaba rodando demasiado al límite porque le estaba presionando mucho?", preguntaron al mallorquín. "Evidentemente ${ }_{\text {[vis] }}$, no iba de paseo, pero los Bridgestone tienen este problema", respondió. "El problema viene cuando no esperas que el neumático esté frío [...].” (El País, 8 June 2010)

'Was it the tires' fault or Lorenzo's fault? "Was he going too close to the limit because he was under pressure?", they asked the Majorcan. "Evidently, he wasn't going for a walk, but the Bridgestone tires have this problem", he answered. "The problem shows up when you don't expect the tires will be cold [...]."'

(5) [...] como si de repente habitáramos en el interior de una pelota de papel arrugada por un niño. Evidentemente ${ }_{[\text {inf] }}$ existe una frontera invisible en los alrededores de un agujero negro [...]. Si nos acercamos demasiado al abismo veremos cosas que jamás nadie creería [...]. ） (El País, 18 May 2010)

'[... ] as if we suddenly lived inside of a ball of paper ruffled by a child. Evidently, an invisible frontier exists near a black hole [...]. If we get too close to the edge we will see things that nobody would believe [...]? 
It is reasonable to think that in example (4) evidentemente is used to express visual evidence because the interviewer and the interviewee speak about a competition that both persons or at least the interviewee have/has witnessed. The uses in examples (3) and (5), on the other hand, seem to be inferential ones. In example (3), the affirmation that recently fewer foreigners are coming is due to statistical data available to the speaker, from which he draws the conclusion. The speaker in example (5) mentions an 'existing invisible frontier' that firstly cannot be experienced visually and that secondly represents a kind of description of the current situation. The uttered inference is due to his/her experience, or rather perception of the situation. So these three examples and two different meanings are one reason to only analyse utterances which are embedded in context:

Evidential meanings are not simply restricted to single utterances (utterance is used here to cover pragmatic instantiations of language, be these spoken or written) but are perhaps best explored and understood across connected utterances, in identifiable contexts, at levels coherent with more extended instantiations of language use, where the role of evidentiality in discourse is most readily apparent. (Hoye 2008: 152-153)

Kärkkäinen, who studied the linguistic encoding of epistemic stance in English conversation, explains the importance of context, illustrating this with the use of I think:

When a token of I think appears in context, it becomes impossible to determine its precise semantic meaning out of context, on its own and independent of the utterance in which it occurs. [...] the linguistic context of the speaker's current turn provides clues as to which aspect of meaning, doubt or the speaker's (strong) commitment to the truth value, is foregrounded. (Kärkkäinen 2003: 111)

The following example containing a form of Spanish pensar 'think' emphasizes this:

(6) El rival será el Fulham, la gran sorpresa de esta competición y un equipo del que Quique no se fía: "yo desconfío siempre de los equipos que llegan a una final. Pienso que seguramente será un equipo muy competitivo y muy inglés, es decir, muy difícil." (El País, 2 May 2010)

'The rival will be Fulham, the big surprise of this competition and a team Quique does not trust: "I never trust teams who get to the final. I think it will certainly be a very competitive team and very English, that is, very difficult." 
The presence of seguramente 'certainly, surely' and the future form será 'will be, must be', which are found at the sentence level, help to determine that pienso que is used inferentially. Squartini (2001: 321) has shown that Spanish será is a prominent linguistic device to express inference. So here pienso que is surrounded by a context that is inferential in nature. The utterance before the one containing pienso que may support this: the speaker always distrusts (socker) teams that get to the final (yo desconfio siempre de los equipos que llegan a una final). That means the speaker draws a conclusion out of his experience. In Willet's terms it is an inference belonging to the subcategory "reasoning" (1988: 57). ${ }^{4}$ Hence, it could be concluded that pensar is not inherently inferential. Its inferential meaning is actually contributed by seguramente, será and the utterance before. Cappelli (2007: 185) developed the schema set out in Table $1^{5}$ for English think, which could be also applied to Spanish pensar.

Table 1. The conceptual dimensions lexicalized by think

\begin{tabular}{|c|c|c|c|c|}
\hline \multirow{2}{*}{\multicolumn{2}{|c|}{ Evidentiality }} & \multicolumn{2}{|l|}{ Epistemicity } & \multirow[t]{2}{*}{ Cognition } \\
\hline & & Likelihood & Certainty & \\
\hline Think & Non-inherent & Positive degree & $\begin{array}{l}\text { Highly variable } \\
\text { according to the } \\
\text { context }\end{array}$ & $\begin{array}{l}\text { Computational pro- } \\
\text { cess over available } \\
\text { evidence }\end{array}$ \\
\hline
\end{tabular}

As Cappelli points out, the English verb does not inherently lexicalize evidentiality. Concerning this category, it can be said that Spanish pensar is used in a similar way as English think.

Analysing the epistemic-evidential use of modal adverbs and verbs of cognitive attitude also means to look at the mood of the verbal forms because "[...] the subjunctive is often used to express [...] doubt, especially with adverbs, in contrast with the indicative which expresses greater confidence: Tal vez venga mañana, Tal vez vendrá mañana" (Palmer 1986: 66; cf. also Haverkate 2002: 35-37).

Furthermore, as indicated above, I should go beyond the sentence level due to the context-sensitiveness of this study. Finally, in the analysis

\footnotetext{
${ }^{4}$ Plungian (2001: 354) differentiates between synchronous inference, retrospective inference and reasoning. He describes the first as "P, because I can observe some signs of P [P at $\left.\mathrm{T}_{0}\right]$ ", the second as " $\mathrm{P}$, because I can observe some traces of $\mathrm{P}\left[\mathrm{P}\right.$ before $\mathrm{T}_{\mathrm{o}}$ ] and the third as "P, because I know Q, and I know that Q entails P".

5 The tables proposed by Cappelli summarise the "semantics" (Cappelli 2007: 224) or "conceptual dimensions" lexicalized by a certain verb (ibid.: 185).
} 
of individual items an attempt will be made to determine which meaning aspects are encoded and which ones are contributed by the context. Is it really possible - in the realm of the use of verbs of cognitive attitude and modal adverbs - to differentiate between evidentiality and epistemic modality? Dendale \& Tasmowski (2001: 345) state, not without reason, that in several languages certain linguistic expressions are used to express both linguistic categories, although not (always) simultaneously. These expressions then blur the conceptual distinction (Squartini 2004: 874).

\section{A context-sensitive study of verbs of cognitive attitude and modal adverbs in Spanish}

\subsection{The epistemic and evidential use of Spanish modal adverbs}

In this section the use of the modal adverbs aparentemente, evidentemente, obviamente, probablemente, posiblemente, supuestamente and seguramente is analysed and it will be shown that

[s]everal [...] adverbs (and adverbial phrases) express reference to knowledge and, by doing so, verbalize the evidential justification for the speech act: ${ }^{6}$ aparentemente [. . .], evidentemente, obviamente, supuestamente [.. .]. These expressions convey evidential values such as various types of inferences and hearsay. (Cornillie 2010a: 300)

When it is required, special attention is paid to the mood of the verbal form used in the utterance containing the adverb under question because " $[\mathrm{m}]$ odal variation in sentences where the dubitative adverb precedes the verb has been generally explained in terms of the greater or lesser degree of uncertainty of the speaker concerning the truth value of the statement" (Haverkate 2002: 35).

As will be shown below (and as was already shown by the examples (3), (4) and (5) containing evidentemente), certain modal adverbs are sometimes used to express inference, sometimes hearsay, sometimes vis-

\footnotetext{
${ }^{6}$ Cf. Boye's article "Evidence for what? Evidentiality and scope" (2010). The aim of this article is to show that evidential meanings "are all conceptually dependent on a proposition, as opposed to a state of affairs and a speech act" (Boye 2010: 291). Although I am aware of the notional distinction, 'proposition' and 'state of affairs' will be used synonymously in the present study as a proposition is the linguistic representation of a state of affairs (cf. Cappelli 2007: 122-123).
} 
ual evidence and sometimes a mixture of inference and visual evidence. Therefore, I will use the following subscript abbreviations: '[inf]' for inference, '[vis]' for visual evidence, '[hs]' for hearsay and '[inf/vis]' for a mixture of inference and visual evidence.

\subsubsection{Aparentemente}

As the data show, aparentemente has three meanings, out of which the context determines the (more or less) exact meaning:

(7) Hoy, el técnico de La Oranje se encuentra a un partido de hacer el Mundial perfecto y ganar todos los partidos desde que en 2008 comenzara la clasificación para Sudáfrica. Van Marwijk ha transformado al equipo en una cosechadora de resultados aparentemente ${ }_{\text {[vis] }}$ infalible, cuya última prueba será la final del Mundial que disputará ante España. (El País, 11 July 2010)

'The Holland coach is one match away from playing a perfect World Cup and winning all the matches since 2008 when qualification for South Africa started.Van Marwijk has changed the team into a threshing machine that obtains results apparently unfailingly and its last test will be the World Cup final, playing against Spain.'

(8) Los medios de comunicación rusos, sin embargo, se refieren a cuatro condenados por espionaje y traición al Estado y de ese supuesto parte, aparentemente $_{[\mathrm{hs}]}$ el decreto de indulto firmado por el presidente Dmitri Medvédev sobre el que informó el viernes la página oficial del Kremlin. (El País, 12 July 2010)

'The Russian media, however, refer to four convicted for espionage and betrayal against the State and from this assumption, apparently, emerges the decree of absolution, signed by president Dmitry Medvedev, as the official Kremlin web page informed last Friday.

(9) Vaz ha publicado La otra mujer (2003), Leña (2004) y Metástasis (2006), entre otros. La poeta se ha dedicado, además, a asuntos tan aparentemente $_{\text {[vis] }}$ contradictorios como la gimnasia rítmica, la filosofía -es licenciada por la Universidad de Sevilla-, el periodismo y las artes plásticas. (El País, 4 Apr. 2010)

'Vaz has published La otra mujer (2003), Leña (2004) and Metástasis (2006), among others. Moreover, the poet has dedicated herself to such apparently contradictory topics as rhythmic gymnastics, philosophy 
- she has a B.A. from the University of Seville - journalism and plastic arts.'

(10) Con 87 años, sorda y aislada, no se habla con su única hija, Françoise, a causa de la denuncia que ésta interpuso contra su amigo, el fotógrafo François-Marie Banier. La millonaria apareció el viernes en televisión: aparentemente $_{[\text {inf/vis] }}$ lúcida a pesar de la sordera, se fue por la tangente a la hora de responder sobre su presunto delito de evasión fiscal. (El País, 8 July 2010)

'At the age of 87 , dumb and isolated, she does not speak with her only daughter, Françoise, because of the denunciation she made against her friend, the photographer François-Marie Banier. On Friday, the millionaire lady appeared on TV: apparently lucid, despite her difficulty in hearing, she avoided answering the questions about her presumed crime of tax evasion.'

Examples (7), (9) and (10) contain the construction modal adverb + adjective (infalible 'never failing/faultless', contradictorio 'contradictory', lúcido 'lucid'). In these examples aparentemente is used to express visual evidence because the characteristics described by the adjectives are visually perceptible, although they may be accompanied by an inference, as example (10) demonstrates: the speaker infers from visual evidence - from the appearance of the woman - that she is still a lucid person.

Cornillie (2010b: 315) has shown that aparentemente is used to convey not only the inferential reading but also hearsay. This can be confirmed by example (8), where the information of an explicit web page is reported so that the use, strictly speaking, conveys the reported reading. The literature usually differentiates between "cases in which the context allows for the source of the proposition to be identified, and those in which this is not the case, using the labels 'reported' and 'hearsay' [. . .], respectively" (Olbertz 2007: 154). Example (8) contains references to possible information sources (the underlined phrases) that may go hand in hand with aparentemente.?

While inference and visual evidence are assumed to represent meaning aspects that are encoded by aparentemente, the hearsay/reported meaning is considered to be contributed by the context as the adverb - if used to con-

${ }^{7}$ I admit that it could be argued that 'the official Kremlin web page' (example 8) is also visually perceivable. 
vey reported/hearsay evidence - needs to appear with further references to information sources such as the underlined phrases in the example. One could conclude that if aparentemente does not appear together with other references to information sources the meaning conveyed is either visual evidence or inferential evidence or both.

\subsubsection{Evidentemente}

The adverb evidentemente seems to have similar functions as aparentemente, thus it is not used to indicate reported/hearsay evidence:

(11) [...] confrontación por un proyecto integrador, en el que todos, incluidos los nacionalismos democráticos, puedan sentirse comprometidos [...] con el desarrollo del Estado democrático y corresponsables con el proyecto europeo de la España plural. Pero, evidentemente ${ }_{\text {[inf, }}$ la tarea no es fácil. Entre otras razones porque ese proyecto federal implica una importante reforma constitucional. (El País, 23 July 2010)

'[...] confrontation because of an integrating project with which all, including the democratic nationalists, can feel committed [...] with the state's democratic development and responsible for the European project of 'Plural Spain'. But, evidently, the task isn't so easy. Among other reasons because that federal project implies an important constitutional reform.

(12) [... en el hecho de que el porcentaje de españoles capaz de comunicarse fluidamente en inglés sea muy inferior al de la población nórdica, la germánica o incluso la de algunos países eslavos. Los motivos son de tipo cultural, educativo $y$, evidentemente $e_{[\text {[inf/vis] }}$ también lingüísticos. Comencemos por estos últimos. El español, y nuestras otras lenguas románicas (a las que habría que añadir también el vasco), no pertenecen a la familia lingüística del inglés, que es el grupo de lenguas germánicas [...]. (El País, 21 July 2010)

'[...] in the fact that the percentage of Spanish people able to communicate fluently in English is lower than in Nordic and Germanic countries, and even than in some Slavic countries. The reasons are cultural, educational and, evidently, also linguistic. Let us start with the latter: Spanish and the other Romance Languages (to which Basque should be added), do not belong to the language family of English, which is the group of the Germanic languages [...].' 
(13) “[... Nosotros recomendamos dedicarle a las tareas de 30 a 40 minutos diarios, de lunes a viernes, como en el calendario escolar," explica Ortiz. La franja de edad de estas tareas incluye incluso a los pequeños de tres años que, evidentemente ${ }_{[\text {inf } / \text { vis] }}$, aprenden a partir de juegos. La mejor hora es después del desayuno, cuando el niño está descansando intelectualmente y cuenta con todo el día por delante. (El País, 9 June 2010)

“"[...] we recommend doing daily exercises of 30 to 40 minutes, from Monday to Friday, as in the school calendar", explains Ortiz. The age range for these tasks includes even little children of three years of age who, evidently, learn by playing. The best time is after breakfast when the child is still intellectually 'fresh' and has all day ahead of it.'

(14) Este fenómeno sería como un subproducto que fabricaba la cultura burguesa para anestesiar al burdo proletariado. Todos los medios de comunicación de masas desarrollaban la función de hipnotizar a las masas. El fútbol, evidentemente ${ }_{\text {[vis] }}$ en uno de los primeros puestos. Pero ¿qué ocurre, sin embargo, ahora cuando la Wikipedia es el centro del saber [?] (El País, 21 July 2010)

'This phenomenon would be like a by-product, produced by the bourgeois culture to anaesthetise the proletariat. All the mass media developed the function to hypnotize the masses. Football, evidently, in one of the first places. But what happens now that Wikipedia becomes the centre of knowledge [?]'

Evidentemente in (11) is clearly used inferentially as the context indicates: [. . .] la tarea no es fácil. Entre otras razones porque ese proyecto federal implica una importante reforma constitucional, . . . this task is not easy. Among other reasons because ..... The speaker infers the state of affairs (the difficulty or non-easiness) and justifies his utterance giving the reason (porque...). Reyes (1996: 28-29) has already shown that evidentemente is often used when a state of affairs is not visually perceptible. The use of the modal adverb in examples (12) and (13) can be interpreted as both visual evidence and inference: The fact that Spanish belongs to another language family than English is evident or obvious but it has to be inferred that this is one reason to explain why Spanish people often have difficulties to speak English (example 12). The use of evidentemente in (13) can be explained in similar terms: Ms or Mr Ortiz surely monitored children when they learned from playing, but she/he simultaneously had to infer that what the children did was learning (by playing). In (14) we clearly deal with a use of evidentemente to indicate visual evidence because that media use football 
to hypnotize people represents a phenomenon that is visually perceptible. For the English equivalent, Simon-Vandenbergen \& Aijmer found out that evidently also has a hearsay meaning (2007: 161). The hearsay meaning for evidentemente could not be verified in the course of this study, as I did not come across uses that could be compared with the use of aparentemente in example (8).

Concerning the question which meaning aspect could be assumed to be encoded by evidentemente and which one could be contributed by the context, visual evidence appears to be encoded and inferential evidence contributed by the context because the inference is often based on visual evidence or at least on something that is perceivable like the situation described in example (11). Furthermore, the reason why the speaker concludes that $[p]$ is also shown by the underlined phrase that supports the inferential use.

\subsubsection{Obviamente}

"Obviously means 'as evidence shows'. Hence, obviously, even in its extended evidential meaning of 'as knowledge of the world shows' [. . . ] is evidential, meaning 'as the evidence shows'" (Simon-Vandenbergen \& Aijmer 2007: 220). But sometimes 'obvious evidence' has to be interpreted by the speaker, and then it is also used inferentially, although these are not two different meanings or functions of obviamente. It seems really difficult to differentiate the two:

(15) Sentado en el sillón de su despacho en el centro de Washington, Moreno, colombiano de 57 años, está exultante de felicidad el martes por la tarde, minutos después de haber sido renovado en su cargo para un segundo periodo de cinco años. Su alegría, obviamente, responde al reconocimiento por el éxito de su gestión. Pero él la justifica por "el honor de ocupar este puesto en un momento particularmente positivo para este continente." (El País, 10 July 2010)

'Sitting in an armchair in his office in the centre of Washington, Moreno, a 57-year-old Colombian, is so happy on Tuesday afternoon, a few minutes after having been re-elected for a second period of five years. His happiness, obviously, is brought about by the recognition of his successful administration. But he says it is due to "the honour to be here at such a positive moment for this continent." 
In example (15) the speaker/writer tries to explain the reason for $\mathrm{Mr}$. Moreno's happiness. The speaker/writer could see that the person under question is happy but the reason for Moreno's happiness is an inference, as the context shows.

(16) Aira recordó sus inicios como traductor de best-sellers ("me decanté por ellos cuando descubrí que pagaban lo mismo por traducir buena que mala literatura; y que la mala resultaba obviamente más fácil") y cuánto estos influyeron en su inclasificable estilo. (El País, 13 July 10)

'Aira remembered her beginnings as a translator of best-sellers ("I couldn't believe it when I discovered that they paid the same for translating good literature as well as bad literature; and that translating bad literature was obviously easier") and how much these [best-sellers] influenced her unclassifiable style.'

(17) Si hay un pueblo que carece de sentido de Estado es el italiano. El único periodo en el que se produjo un breve y ficticio sentido de Estado fue bajo el fascismo [...]. Obviamente, las dictaduras son algo terrible, que eliminan las libertades [...], pero representan una fuerza unitaria cohesionadora [...]. (El País, 15 July 2010)

'If there is a nation that does not have an understanding of State, it is the Italian nation. The only period when an almost fictitious understanding of State arose, was under fascism [...]. Obviously, dictatorships are something terrible that eliminate freedom [...], but they represent unitarian power [...]'

The use in (16) and (17) seems to indicate what was already quoted: 'as evidence shows' or 'as knowledge of the world shows' while the former would apply to example (16), the latter applies to example (17). In example (16) a translator speaks about his personal experience that badly written literature can be translated obviously with less effort. The fact expressed in example (17) is indeed something that is part of knowledge of the world.

Simon-Vandenbergen \& Aijmer have shown for obviously that "it 'inherently' refer[s] to the fact that the information can be gathered from available evidence" (2007: 38), that it "convey[s] certainty based on some kind of evidence which is there for everyone to see" (2007: 147), that its meaning 'obvious to everyone' makes it more "intersubjective rather than subjective" (2007: 150) and that it is consequently used to present information as common ground so that its function "is bonding: the creation of shared attitudes, a common world", whereby the speaker conveys 'I know that you 
also know this' (2007: 154). These characteristics are all applicable to the examples cited above. Therefore I conclude that the meaning of obviamente is not as much context-dependent as the meaning of aparentemente, for instance. Obviamente nearly always seems to express 'as evidence/knowledge of the world shows'; only the use of the adverb in passage (15) represents an example where the use is accompanied by an inference based on observable evidence.

\subsubsection{Posiblemente}

Posiblemente expresses a possibility (of a state of affairs); its nearest English equivalent is 'possibly'. Probablemente 'probably', on the other hand, expresses likelihood (of a state of affairs). And likelihood of a state of affairs is more probable than possibility. So I could conclude that a probability expresses a greater possibility, and that a possibility is less probable than a probability:

(18) La localidad de Rothbury, un pequeño pueblo del noreste de Inglaterra cuya población no llega a los 2.000 habitantes, ha vivido esta semana posiblemente algunos de los días más intensos de su historia. Desde el martes, decenas de agentes británicos, apoyados por helicópteros, acordonaban la localidad para intentar apresar a Raoul Moat, al que llevaban buscando desde el pasado sábado [...]. (El País, 12 July 2010)

'The town of Rothbury, a little village in the North-East of England, whose population is under 2,000, experienced this week probably some of the most intense days in its history. Since Tuesday, dozens of British agents, supported by helicopters, surrounded the area to capture Raoul Moat who was being pursued since last Saturday [...].'

(19) [...] fue "como volver a casa, porque los tres venimos del mismo sitio, somos músicos de jazz, pero nunca habíamos tocado en acústico. El año que viene tenemos la idea de montar una gran fiesta, posiblemente en San Francisco, aprovechando que fue allí donde nos reunimos por primera vez. Esa ciudad tiene un sonido especial que viene de los tiempos del Fillmore y las bandas de rock de los sesenta". (El País, 12 July 10)

'[...] it was "like coming back home because the three of us came from the same place, we are jazz musicians but never before had we played 'acoustic'. Next year we want to organize a big party, possibly in San Francisco, because it was there where we met the first time. That city 
has a special sound that dates back to the times of Fillmore and the rock bands of the 1960s."'

(20) Tras 45 minutos de maniobras, se confirmó el fallecimiento del paciente por parada cardiorespiratoria, posiblemente secundaria a golpe de calor al presentar el joven una temperatura corporal de 41 grados. La causa final de la muerte, tal y como establece la normativa vigente, ha de ser dictaminada por el forense a quien se avisó para que certificara [...]. País, 10 July 2010)

'After 45 minutes it was confirmed that the death of the patient was caused by a heart attack, [and] possibly secondarily caused by the heat, as the boy had a body temperature of 41 degrees. The final reason for the patient's death, has to be determined by the pathologist [...]'.

(21) El fotógrafo ve las cosas de manera diferente y habla de "libertad recobrada" $y$ de toma de distancia con la primera parte de su carrera, pero sin renegar de ella en absoluto. Posiblemente dan fe de ello sus extraños trabajos jacksonianos y el fresco en homenaje a un África exangüe que ilustran estas páginas. (El País, 13 July 2010)

'The photographer sees things differently and speaks about "regained liberty" and about distancing himself from the first part of his career, but without denying it at all. His strange Jacksonian works and his fresco as tribute to a bloodless Africa, which these pages illustrate, possibly bear witness to it.'

Considering these examples, one may conclude that posiblemente is a purely epistemic adverb. None of the given contexts leads to the conclusion that the use of posiblemente is evidential. So the meaning aspect which is encoded by this adverb is clearly that 'a certain state of affairs is/was possibly the case'. The only example where the evidential dimension may be present is passage (20): it could be an inference from the situation and it may be even reasonable to think that the patient died because of the heat, as he had a body temperature of 41 degrees. In that case the inferential meaning would be contributed by the context.

"Nevertheless, it should be noticed that in Contemporary Spanish posiblemente is showing a growing tendency to select the subjunctive, which is true in particular of newspaper style" (Haverkate 2002: 36):

(22) Posiblemente, la creación del Servicio sea un paso decisivo en la configuración de la Unión Europea como actor internacional. (El País, 21 July 2010) 
'Possibly, the creation of the Service may be a decisive step towards the configuration of the European Union as an international actor.'

(23) Esa misma fuente habla de la "fatiga" de los materiales. "No siempre las roturas se producen de forma inmediata", explica. Y apunta a que posiblemente el "traqueteo continuado" de la atracción [.. .] haya hecho disminuir su resistencia. (El País, 21 July 2010)

"That same source speaks about "exhaustion" of the materials. "Not always do the breakings happen immediately", he explains. And he notes that the "frequent clattering" of the attraction [.. .] possibly might have reduced its resistance.'

(24) $R$ [espuesta]-Cataluña es tierra de comercio y no sólo sabrá mercadearse, sino que posiblemente se convierta en uno de los competidores más fuertes de España. (El País, 19 July 2010)

'Answer-Catalonia is a land of trade business and will not only know how to develop into a great market but may possibly turn into one of the most powerful competitors of Spain.'

To sum up, the speaker expresses an even lower degree of epistemic evaluation that a certain state of affairs is/was the case when using posiblemente + subjunctive, than when he uses posiblemente + indicative. If the adverb is followed by the subjuntivo, the use seems to be purely epistemic. Posiblemente is a pure epistemic adverb. If the adverb conveys an evidential meaning, it is a meaning aspect that is contributed by the context (see example (20)).

\subsubsection{Probablemente}

"[...] probablemente [expresses] a low degree of uncertainty, which, in regard to the use of the former [posiblemente], is reflected by the fact that it never takes the subjunctive" (Haverkate 2002: 36). If probablemente is used to express "a low degree of uncertainty", it must express a relatively high degree of certainty:

(25) Ese grupo es el de mayor implantación en la remota región paquistaní de Waziristán, donde también reciben protección y entrenamiento, según los servicios secretos norteamericanos, los jefes talibanes de Afganistán y de Al Qaeda, probablemente el propio Osama Bin Laden. (El País, 12 May 2010) 
'That group is the major one based in the remote Pakistani region of Waziristan, where, according to the US Secret Service, the Taliban chiefs of Afghanistan and Al Qaeda, probably Osama Bin Laden himself, receive protection and training.'

(26) El juez del caso Millet ha sido etiquetado como el caracol, por la presunta lentitud con que avanza el caso. Al golfista Sergio García lo etiquetaron como el niño, probablemente por su aspecto, como también es el niño Fernando Torres, jugador de fútbol. A la modelo australiana Elle McPherson la etiquetaron como el cuerpo, y a Naomi Campbell, como la pantera negra. (El País, 15 June 2010)

'The judge in the Millet case was called "a snail" because of the slow progress of the case. The golfer Sergio García was labelled "a child”, probably because of his looks, just like the boy Fernando Torres, the football player. Elle McPherson, the Australian model, was called "the body", and Naomi Campbell, "the black panther".

(27) "Qué quieres que te diga, qué te voy a decir." "Pues que me digas cómo estás," la aclaró ella. Casillas señaló que era un "momento muy feliz", que estaba "muy contento" y repasó lleno de emoción su lista de agradecimientos a su familia, amigos. . . Probablemente se mordió la lengua para no citar a su novia, a la que tenía delante, se calló, se rió, miró para otro lado, ella le dijo "no pasa nada, vamos a hablar un poquito del partido" y él contestó que no con el dedo. (El País, 14 July 2010)

" "What do you want me to say, what can I say." "Well, tell me how you are feeling," she explained. Casillas explained that it had been a "very happy moment", that he was "very happy" and full of emotion he went through the list of gratitude for his family and friends ... Probably biting his tongue trying not to mention his girlfriend, standing in front of him, he kept quiet, laughed, glanced to the other side. She told him "it doesn't matter, let's talk a bit about the match" and he gestured "no" with his finger.'

In examples (25) and (27) the uses of probablemente simply indicate suppositions, whereas the use in (26) seems to be inferential: it is inferred that the golfer was called a child because of his childlike appearance (probablemente por su aspecto). Nevertheless, as posiblemente, probablemente is an adverb used to express (pure) epistemic modality. I did not come across many examples like (26). Here, the inferential meaning is contributed by the context. Probablemente does not more than express a probability that a certain state of affairs is/was the case. 
Probablemente may select the subjunctive, which seems to be typical of newspaper style, and if so, it expresses a lower epistemic evaluation that a certain state of affairs is/was the case, than if the adverb were used in connection with the indicative:

(28) ¿Practicaban alguna disciplina esotérica? ¿Qué se propusieron?

Probablemente el asunto se archive y nunca sepamos exactamente lo que ocurrió ayer en el estadio Loftus Versfeld. Probablemente los miles de hinchas japoneses y paraguayos que asistieron a la cita, expectantes, olviden pronto estos acontecimientos y solo retengan la consecuencia burocrática. (El País, 2 July 2010)

'Did they practice esotericism? What did they propose? Probably this affair was filed and we may never know what happened exactly yesterday at the stadium Loftus Versfeld. Probably the thousands of Japanese and Paraguayan fans who attended the match may soon forget the event and simply remember the bureaucratic consequence.'

\subsubsection{Seguramente}

For the use of seguramente I expect results similar to those shown for the use of no doubt and undoubtedly by Simon-Vandenbergen \& Aijmer: "Although both no doubt and undoubtedly literally mean that 'there is no doubt' and hence express certainty, they have developed different pragmatic functions" (Simon-Vandenbergen \& Aijmer 2007: 146). Speakers use these adverbs when they have doubt. So I expect for seguramente that it is used if (and only if) the speaker/writer is not sure:

(29) Santos va a enfocarse mucho más que Uribe en el desarrollo social y económico [...]. Seguramente le prestará mucha más atención a la realidad y a la percepción interna y externa del déficit de respeto a los derechos humanos: entiende el problema, y lo quiere atender. También puede -y probablemente lo hará con gusto- librar [...]. (El País, 9 July 2010)

'Santos will focus more than Uribe on the economic and social development $[\ldots]$. He will certainly pay more attention to the reality and the internal and external perception of the deficiency concerning human rights: he understands the problem and he wants to solve it. He can and probably will do so with pleasure - rescue [...]' 
(30) Casi todos los expertos en turismo estarían de acuerdo en que en Europa hay un selecto puñado de ciudades de primerísima categoría. Roma. París. Londres. Probablemente Viena y Praga. Seguramente ninguna más. (El País, 14 July 2010)

'Nearly all experts in tourism would agree that in Europe there are only a few cities that are first rate. Rome. Paris. London. Probably Vienna and Prague. Certainly no more.'

(31) Consciente del enojo que podría haber generado en una buena parte de los 400 millones de internautas con que cuenta el país - entre ellos, seguramente muchos funcionarios del Gobierno y empresas chinas -, consciente del mal efecto que habría supuesto para la imagen de China y para el clima inversor extranjero, Pekín ha decidido renovar la licencia del buscador de Google [...]. (El País, 11 July 2010)

'Being aware of the displeasure that could have been generated in most of the 400 million internet users - among them, certainly many government employees and Chinese companies, conscious of the bad effect that it could have had on China's image and on foreign investors, Peking has decided to renew Google's licence [...].'

(32) Los jugadores se las han ingeniado todas con tal de que se les pasara el mes lo más rápido posible. Camino del paraíso, se evaporaron las dos primeras semanas, seguramente porque la porra organizada por Puyol fue reñida -se la llevaron Piqué y Mata; Capdevila fue segundo-y porque había partidos a todas horas por tele. Algunos siguieron los partidos de Pau Gasol. Otros la final de Wimbledon de Rafa Nadal. （El País, 14 July 2010)

'The players thought about how to let the month pass by as fast as possible. On the way to paradise, the first two weeks evaporated, certainly because the 'competition' organized by Puyol was disputed - Piqué and Mata took it; Capdevila was second - and because there were games at all times on TV. A few watched Pau Gasol's matches. Others the Wimbledon final with Rafa Nadal.'

In (29) the adverb is clearly used to express an inference because it is followed by a verb in synthetic future form (prestará), and the futuro sintético has been shown to express inference (Squartini 2001). ${ }^{8}$ Furthermore, going beyond the sentence level, probablemente + synthetic future (hará)

\footnotetext{
${ }^{8}$ That is why this future form was called futuro de probabilidad (Volkmann 2005: 287).
} 
also seem to express at least (if not an inference) a relatively high degree of epistemic evaluation that a certain state of affairs is the case. Example (30) contains the information that 'Rome, Paris and London are first-class tourist cities. Probably (also) Vienna and Prague. Certainly not more cities'. Cornillie (2010a) explains that "[modal adverbs] in -mente, unlike manner adverbs, can also be transformed into a construction formed by a copula and an adjective. The finite subordinate clause introduced by que is then the subject of the sentence [...]" (Cornillie 2010a: 304). But trying to paraphrase the adverbs with es probable que $[p]$... and es seguro que, the content of the information would be modified (beside the fact that I would need to add a verb): Es probable que Viena y Praga son/sean ciudades de primerísima categoría. Es seguro que ninguna ciudad más es de primerísima categoría. The transmitted information would be modified by paraphrasing the adverb seguramente, whereas the information containing probablemente would not. The reason is that, using seguramente, the speaker wants to express that he is fairly sure that $[p]$, not totally sure that $[p]$. The adverb's use in (31) should be analysed in similar terms as the use in (30). The use or function of seguramente in example (32), on the other hand, seems to be an inferential one because it is part of a subordinate clause indicating the reason with porque. However, the inferential meaning does not seem to be encoded by seguramente; it is contributed by the context. All in all, it seems reasonable to conclude what Simon-Vandenbergen \& Aijmer found for certainly: "The use of certainly [.. .] occurs in a context of uncertainty rather than certainty" (2007: 211).

\subsubsection{Supuestamente}

The adverb supuestamente is often found in contexts having to do with crimes and legal issues, which can be explained by the fact that this adverb "excludes personal experience and reports the observation made by someone else" (Cornillie 2010b: 313):

(33) Skripal, antiguo coronel del Ejército ruso, fue condenado en 2006 a 13 años por realizar actividades de espionaje para Reino Unido. Supuestamente compartió información sobre decenas de sus antiguos colegas que trabajaban encubiertos en Europa, llegando incluso a revelar los lugares en los que tenían lugar reuniones secretas, así como sus direcciones, $y$ contraseñas. (El País, 11 July 2010) 
'Skripal, a former colonel of the Russian army, was convicted in 2006 to 13 years for espionage acts for the UK. Supposedly he shared information about old colleagues who worked undercover in Europe, to the extent that he revealed the places where secret meetings were held, as well as addresses and passwords.'

(34) En aquella operación de 2006 también fueron detenidos en diversos puntos de la provincia de Alicante otros ocho miembros de la organización, entre ellos Isabelle R. y el abogado J. J. S. quien, según la Policía, supuestamente colaboraba en las actividades [...]. (El País, 22 July 2010)

'In that operation of 2006 eight other members of the organization were also arrested in different regions of the province of Alicante, among others Isabelle R. and the lawyer J. J. S. who, according to the police, supposedly cooperated in the activities [...]?

(35) La policía nacional detuvo el jueves a 13 personas, la mayoría de un clan familiar, a las que se acusa de controlar, supuestamente, el tráfico de hachís al menudeo en el barrio de El Cabanyal. Este clan familiar estaba perfectamente estructurada, según fuentes policiales, y utilizaba a personas de origen sudamericano como correos. (El País, 12 July 2010)

'On Thursday the national police arrested 13 people; most of them belonged to a family clan that is accused of supposedly controlling the hashish traffic in El Cabanyal. This family clan was well organised, according to the police, and used people from South America as couriers.'

(36) La última víctima, Andrea Zambrano, ecuatoriana de 28 años y embarazada, había denunciado a su pareja en dos ocasiones, y ayer murió estrangulada supuestamente por él, Marcelo Iván C. E., de 33, en la habitación que compartían en el barrio barcelonés de Sants. (El País, 10 July 2010)

'The last victim, Andrea Zambrano, from Ecuador, 28 years old and pregnant, had accused her partner on two occasions, and yesterday she died, strangled supposedly by him, Marcelo Iván C. E., 33 years old, in the apartment they shared in Barcelona.'

(37) [. . . FBI han detenido en la Gran Vía de Madrid a un estafador internacional buscado por Estados Unidos. El arrestado, R.L, un boliviano de 70 años, estafó 1, 3 millones de dólares a través de una falsa organización caritativa [.. .] que supuestamente ayudaba a niños con necesidades, especialmente en Sudamérica. (El País, 30 May 2010) 
'[...] FBI has arrested a fraud for whom the US had issued an international search warrant. The arrested person, R. L, a 70-year-old Bolivian, conned 1,3 million dollars through a false charitable organization [...] that supposedly helped children in need, especially from South America.'

As the examples above indicate, supuestamente is often used to give information about a crime when the state of affairs is not really clear at the time of writing/uttering the information. The state of affairs that is communicated is still not really certain but supposed. Cornillie (2010b: 313, 315) has shown that supuestamente can encode only a reported reading but I would like to draw attention to the fact that it is very often accompanied by an inferential reading, slightly different though: if we deal with a 'classical' inferential use of a certain linguistic expression, the speaker himself is the person who drew the conclusion, while in the case of supuestamente the speaker/journalist transmits the inferentially gained information from another person (inference + reported). The evidential meaning aspect is thus assumed to be inherent in the adverb.

\subsection{The epistemic and evidential use of Spanish verbs of cognitive attitude}

Nuyts (2001) says that verbs of cognitive attitude "are notoriously difficult to deal with, much more so than the adverbs and adjectives, mainly because of their complex semantic structure and their mysterious linguistic behaviour" (Nuyts 2001: 107). Nevertheless I will try to describe in detail the evidential and epistemic meaning aspects of Spanish verbs of cognitive attitude and to find out which meaning aspects are encoded by the verbs and which may be contributed by the context.

The findings will be compared with the conclusions on the English verbs of cognitive attitude drawn by Cappelli (2007).

\subsubsection{Creer}

[Believe] encodes an affective dimension. By using this verb, the speaker signals that he/she is ready to support his/her assertion with the strength of his/her subjective, affective commitment. The possibility for the verb to lexicalize this dimension means that, besides pointing towards the 
epistemic domain, it also involves evidentiality. The speaker is highly committed to the likelihood that a state of affairs is the case on the grounds of some sort of affective evidence that he/she has for it. (Cappelli 2007: 170)

Let us see how affective and evidential the use of Spanish creer is:

(38) [...] fenómenos culturales, como la película [.. . que provocó una explosión de interés por el Pinot Noir. "Yo creo que el verdadero poder está en el arte de saber contar historias. Esa es la mejor manera de vender, ya sea un vino o una información. Creo que por eso he tenido éxito, porque soy un buen contador de historias". (El País, 11 July 2010)

'[...] cultural phenomena, like the film [...] which caused an explosion of interest for Pinot Noir. "I believe that the real power is in the art of knowing how to tell stories. That is the best way to sell, being wine or information. I believe that is why I have success, because I am a good storyteller"'.

(39) $P[$ regunta]: ¿De quién se ha nutrido usted? $R$ [espuesta]: De muchos, creo que una de las personas que más me ha influenciado es Martín Caparrós y una autora como Susana Orlean que tiene una mirada muy sutil y muy sofisticada que me interesa muchísimo. (El País, 11 July 2010)

'Question: Who inspired you? Answer: Many, I believe that one of the persons who influenced me the most is Martín Caparrós and an author like Susana Orlean, who has a refined and sophisticated approach which I am very interested in.

(40) "[...] Soy optimista de cara a mañana, creo que tenemos opciones de lograr un podio que sería muy bueno. Me gustaría poder poner en aprietos a los Red Bull, aunque creo que será complicado", ha dicho Alonso [...]. (El País, 11 July 2010)

“"[...] I am optimistic about tomorrow, I believe we have the opportunity to achieve a position that would be very good. I would like to make things hard for the Red Bull team, although I believe it will be complicated," Alonso said [...]?'

(41) "[. . . Nos han metido dos goles [...]. Hemos estado sólidos. Yo creo que la base del éxito es una buena defensa, porque luego, con la calidad que tenemos, siempre creo que uno u otro jugador marcará. [...]" (El País, 12 July 2010)

“"[...] They scored two goals, [. . .]. We were solid. I believe the basis of success is a good defence, because later on, having the quality we have, I always think one or another player will score a goal [...]"' 
It seems that it could be verified that the verb creer - as its English counterpart believe - may lexicalize the evidential domain beside the epistemic one. The speaker indeed is "highly committed to the likelihood that a state of affairs is the case on the grounds of some sort of affective evidence that he/she has for it" (Cappelli 2007: 170). Let us consider the examples in detail: in (38) and (39) the speaker uses creo que marking information epistemically/evidentially concerning his own person. That is why the affective dimension is present. In (40) the verb is combined with the synthetic future form será, which emphasizes that we deal with an inferential use. The use in (41) seems to be inferential as well because the subordinate clause, following the clause containing creo que, gives reasons for the speaker's believing. To sum up, Table 2 for English believe, developed by Cappelli (2007: 172), seems to be valid for Spanish creer as well.

Table 2. The conceptual dimensions lexicalized by believe

\begin{tabular}{llll}
\hline \multirow{2}{*}{ Evidentiality } & Epistemicity & \\
\cline { 3 - 4 } believe & $\begin{array}{l}\text { Affective evidence } \\
\text { Affective dimension } \\
\text { present }\end{array}$ & Positive degree & $\begin{array}{l}\text { Certainty } \\
\text { but fairly committed }\end{array}$ \\
\hline
\end{tabular}

\subsubsection{Pensar}

[Think] has a very general meaning, roughly equivalent to "cognize" which, according to the context, is construed as a judgement over available evidence or as a personal opinion. [...] the evidential dimension does not seem inherently present in the verb. Think is therefore a purely epistemic verb, which can either be interpreted as "in my opinion" or "maybe". (Cappelli 2007: 185)

These words apply to Spanish pensar, too, even though the verb may convey an inferential reading from contextually provided information as in (43), below:

(42) "[...] Dentro de un solo vino puedes ver no sólo diferentes sabores, sino también filosofías, lugares y personas. El vino griego proviene del corazón del pueblo heleno", señala Lazarakis por vía telefónica. "Por eso pienso que quien de verdad ame el vino tiene mucho que descubrir en el vino griego", añade. (El País, 22 July 2010) 
“" [. . I In one single wine you can see not only different tastes, but also philosophies, places and people. Greek wine comes from the heart of the Greek people," explains Lazarakis on the telephone. "That is why I think who really loves wine has a lot to discover in Greek wine," he adds.'

(43) Estudié periodismo [...]. Me puse a trabajar muy pronto, a los dos años [...]. ¿Qué sabía hacer yo? Escribir, por eso a veces pienso que con la primaria me bastaba. Ahí me enseñaron a poner sujeto, verbo y predicado. Bueno, hace falta cabeza. (El País, 13 July 2010)

'I studied journalism [...]. What were the skills I had? Writing; that is why I sometimes think that primary school would have been enough for me. There I was taught where to place the subject, verb and predicate. Well, you need to think.'

(44) "Todo esto viene de algo muy profundo", explicó la modelo de 40 años. "Viene de otro tipo de desorden emocional porque no se trata de que si no se hace lo que quiero tiro cosas. Pienso que deriva de un tema de abandono y de que he intentado construir una familia con gente que no lo es. Entonces, cuando siento que traicionan mi confianza, me derrumbo. Veo todo rojo". (El País, 7 May 2010)

“"All this comes from something very deep," explained the 40-year-old model. "It comes from another type of emotional disorder because it isn't a question of me throwing things when they don't do what I want. I think it derives from a feeling of abandonment and that I tried to create a family with people who aren't relatives. Therefore, when I feel that they betray me, I break down. I see everything red."

(45) “[...] Yo nunca he pedido explicaciones a nadie. Llegó un momento en que pensé: 'Hay que vivir con esto [...]'. Pienso que hice lo correcto y que el equipo también obró correctamente". Ante la insistencia, reconoce un posible error: "No me he dedicado a ser entrenador [...]" (El País, 8 May 2010)

““[... I I have never asked anyone for an explication. It got to a point where I thought: 'You have to live with it [... ].' I think I did right and that the team did right too". When pressed, he recognizes a possible error: "I have never worked as a coach [...]"

Example (43) contains at sentence level - beside pienso que - por eso, indicating the reason why the speaker thinks that $[p]$, which clearly signals the inferential use of pensar. Comparing this use to that in (42), it is slightly different because of contextual clues: in (43) the use is inferential because 
the writer concludes that after having learned to write he has learned sufficiently for his professional life. Considering the use of pensar in connection with por eso in (42) we are dealing with a different case: The speaker simply gives a reason for his belief. 'The Greek wine comes from the heart of Greece, and that is why I think that persons who love wine must see something special in Greek wine'. I cannot call this use inferential because the second clause containing pienso que does not represent a conclusion drawn from the preceding clause. Examples (44) and (45) are special cases in so far as the speakers refer to themselves when they state that they believe a certain state of affairs. In (44) the model tries to explain why she behaves in a certain way. The speaker in (45) evaluates the current situation he finds himself in, perhaps judging that he had done all correctly (Pienso que hice lo correcto ...).

Although evidentiality is not inherent in the semantics of the verb, it can be used in contexts in which evidence for the epistemic judgement is explicitly provided (see 43). So an inferential reading is possible from contextually provided information. In comparison to other verbs such as saber, which is said to inherently involve some sort of evidentiality, the evidential meaning is not encoded by pensar.

\subsubsection{Saber}

In ordinary everyday communication, if a sentence bears no explicit marks of evidential-epistemic information, the hearer is allowed to infer that $p$ is a piece of knowledge: in other words, we can assume that in assertions the cognitive attitude expressed by I know is implicitly stated. This brings about the interesting question of why, on occasion, the speaker feels the need to make this attitude explicit. (Cappelli 2007: 156)

The following examples will show why (Spanish) speakers feel the need to make their cognitive attitude explicit. They do so, for instance, when they want to express a very high degree of epistemic evaluation that a certain state of affairs is the case, in other words, when they want to emphasize their commitment to the state of affairs (46); when they express an inference they really believe in (50); or when they are able to even give reasons for why they know the state of affairs to be so $(47,48,49)$ :

(46) Ya sé que esto no es más que un juego, y que solo el hecho de que esa pelotita puñetera entre o no en la portería separa el desengaño de la gloria. 
También sé que nuestros graves problemas como país siguen ahí con victoria o sin ella, pero el otro día España era un solo corazón ilusionado empujando a esos chicos que se dejaban la piel en el campo. (El País, 12 July 2010)

'I know it's just a game and that whether that damn ball goes in or not differentiates defeat from glory. I also know our big problems as a country are still there with or without victory, but the other day Spain was full of hope supporting those boys who were giving it everything.'

(47) El cónsul de Marruecos, Mohamed Said Douelfakar, alabó la "cada vez mayor cooperación" [. . .]. José Antonio Martín, de 52 años, dueño de esta empresa de babel, dijo entender bien a los extranjeros. Quizás porque el también lo fue: "Sé lo que sienten porque en 1980 me enrolé como marinero en un barco de Angola. Allí reuní dinero para comprar mi primera hectárea". (El País, 12 July 2010)

'The consul of Morocco, Mohamed Said Douelfakar, praised the "each time better cooperation" [.. .]. José Antonio Martín, 52 years old, owner of this business, said that he could understand foreigners well. Perhaps because he was one too: "I know how they feel because in 1980 I enrolled on a ship in Angola. There I saved money so that I could buy my first hectare [of land]."'

(48) “[. . [ Los tontos y los poetas tienen a veces intuiciones geniales, lo sé por mi experiencia de tonto. [...]” (El País, 13 July 2010)

“" [. . . F Foolish people and poets sometimes have brilliant intuitions; I know because of my experience as a fool. [.. . ]"”

(49) “[. . . en una crónica de la sección de Cultura, de que voy a publicar un libro en una colección de literatura infantil en la Editorial Alfaguara. Por experiencias muy cercanas, y por libros muy queridos y admirados por mí, sé lo difícil que es escribir para los niños [...]” (El País, 3 May 2010) " " [...] in a report in the cultural section about the fact that I am going to publish a book in a series of literature for children with the publishing company Alfaguara. Thanks to personal experience, and to some books I love and admire, I know how difficult it is to write for children [...]"”

(50) "[. . ] los pilotos de motos no están majaretas, y digo eso [. . .] a todos aquellos que ahora aprovecharán una noticia tan fantástica como es el regreso de Valentino [.. .]. Conociéndole un poquito, sé que lo habrá calculado todo antes de tomar una decisión tan trascendental y arriesgada como esta. [...]" (El País, 17 July 2010) 


\begin{abstract}
“'[...] motorcycle racers aren't crazy, and I say this [...] to all those who now will take advantage of the news of Valentino's return [. . . ]. As I know him a bit, I know he will have thought about it before taking such a vital and risky decision [...]"'
\end{abstract}

In example (46) the evidential dimension of saber is not confirmed by the context compared to examples (47) to (50), where the contextually provided information underlines that saber is a verb that is used not only epistemically but also evidentially. In example (46), there are no clues in the context that the verb is used to express inference or any other kind of evidence. But although not specified, "[r]eference to the availability of evidence, either objectively reliable or subjectively considered as such, is inherent in the semantic potential of the verb" (Cappelli 2007: 166). But the speaker in (50) uses sé que to express an inference, which is indicated by the introductory phrase Conociéndole un poquito 'Knowing him a little', as well as by the futuro sintético following sé que. The speakers of examples (47), (48) and (49) give reasons for their knowing, they justify their knowing: the utterances all contain porque or por ( $\mathrm{mi}$ ) experiencia $(s)$. That means that the speakers somehow infer a certain state of affairs from their own life experience. "The type of evidence that is said to lead to knowledge ranges from objective sensory evidence to very subjective affective evidence" (Cappelli 2007: 166). So in saber, the two dimensions - the epistemic and the evidential one - are present. Consequently, Cappelli's table for know (2007: 166) applies to the use of its Spanish counterpart as well. When a speaker uses saber, he implies that he has some reason for his knowing, and this reason can be and often is specified in context but does not have to be.

Table 3 The conceptual dimensions lexicalized by know

\begin{tabular}{llll}
\hline \multicolumn{2}{c}{ Evidentiality } & Epistemicity & \\
\cline { 3 - 4 } & & Likelihood & Certainty \\
\hline Know & Unspecified but reliable & Positive degree & Highest possible degree \\
\hline
\end{tabular}

\title{
3.2.4. Suponer
}

For the English equivalent of suponer Cappelli found that "[. . .] suppose, when used as a verb expressing the cognitive attitude of the evaluator, lexicalizes a relatively low committed epistemic evaluation that a certain state of affairs is the case, reached via an inferential process" (Cappelli 2005: 
Table 4. The conceptual dimensions lexicalized by suppose

\begin{tabular}{llll}
\hline & Evidentiality & Epistemicity & Cognition \\
\cline { 2 - 3 } & Likelihood & Certainty & \\
\hline Suppose Encoded & Positive degree & $\begin{array}{l}\text { Very low level } \\
\text { of commitment }\end{array}$ & $\begin{array}{l}\text { Dynamic inferential } \\
\text { process, usually } \\
\end{array}$ \\
& & presented as still \\
& & ongoing, resulting in \\
& & a provisional tentative \\
& & conclusion. \\
\hline
\end{tabular}

240). So with suppose the speaker expresses an inference he is not totally sure of. The inferential process is a dynamic one so that the conclusion is tentative and provisional in nature. Hence, Cappelli (2007: 224) proposes Table 4 for suppose. I will try to work out whether this applies to suponer, too:

(51) "[. . . A A mi no me extraña. ... siendo como es, sin duda estará el hombre toda su vida dudando de quienes le rodean, sospechando que una eventual mujer solamente lo querrá por su dinero. Es el precio de la fama supongo. En este contexto, lo mejor que puede hacer es [...]” (El País, 11 July 2010)

“"[.. .] It doesn't surprise me . . being like he is, there is no doubt the man will be doubting all his life of the people who surround him, assuming that a woman will only love him because of his money. It's the price of being a celebrity, I suppose. In this respect, the best thing he can do is [...]"'

(52) $P$ [regunta]. Han jugado más de 75 partidos juntos [. . . Y Y además, son amigos fuera del campo. ¿Eso ayuda? R[espuesta]. Supongo que sí, porque cuando estamos juntos hablamos mucho de fútbol, nos gusta. Somos como una pareja de hecho. (El País, 12 July 2010)

'Question: You have played more than 75 matches together [...]. And furthermore, you are friends outside the football pitch. Does this help? Answer: I suppose so because when we're together we speak a lot about football, we like it. We are like a married couple.'

(53) Cuando Contador le pasa, imagino que Contador ve que algo raro le pasa a Schleck, tal vez haya visto la salida de cadena, pero supongo que habrá pensado "ok si se le ha salido la cadena, tardará 5 segundos en ponerla". 
Contador también tenía pensado atacar al final del puerto. No tiene sentido que ya una vez lanzados los ataques, Contador pare, espere a Shleck [...]. (El País, 22 July 2010)

'When Contador passes him, I imagine Contador sees something strange is happening to Schleck, maybe he has seen the chain jump out, but I suppose he must have thought "fine, if his chain has jumped out, it will take him five seconds to put it back on." Besides, Contador intended to attack him at the end of the port. It doesn't make sense that once the charge has begun Contador should stop and wait for Schleck [...]?

Analysing examples (51) and (52) I could conclude for Spanish suponer what Cappelli states for the use of suppose:

As far as the evidential information lexicalized is concerned, suppose indicates an ongoing inferential process. In certain cases, it can be used to indicate a suddenly reached conclusion based on inferential work following from the evaluation of available evidence of various sorts. (Cappelli 2007: 224-225)

The verb in (51), for instance, is partly used epistemically, partly used inferentially: the speaker assumes that all VIPs have to pay for being famous, that is, epistemically evaluating the state of affairs. On the other hand, the use of supongo may also indicate an inferential process. The fact that the verb is located at the right periphery of the sentence may reflect the fact that we are dealing with a conclusion that has been reached suddenly, and is thus postpositioned.

According to Cappelli suppose "is a verb that can occupy many different positions along the epistemic scale, as it is very sensitive to contextual variables" (Cappelli 2007: 224). The commitment expressed by the speaker in examples (52) and (53) is higher than that in example (51). The use of porque 'because' introducing the clause why the speaker supposes what he supposes (example 52), underlines the fact that suponer is also used when the commitment to the state of affairs is fairly high, and the preceding inferential process is somehow justified. Example (53) is very special as it contains a verb of imagination (imagino que ...), a modal adverb (tal vez 'maybe') + a subjunctive form (haya visto), the verb suponer + a futuro compuesto form (habrá pensado), an imperfecto form (tenía pensado) and a justification introduced by No tiene sentido que 'It does not make sense'. In this context these lexical and grammatical means make clear that the speaker imagines having been in Contador's situation. Therefore, all his 
utterances are to be understood as a supposition and his personal opinion, and simultaneously as a relatively high level of commitment to the epistemic evaluation that a certain state of affairs was the case. However, he distances himself via the use of the subjunctive, the synthetic future and the imperfecto, all indicating uncertainty concerning the state of affairs under question (using subjuntivo and imperfecto) or inference (using futuro sintético). Consequently it can be concluded with Cappelli:

Suppose usually introduces the sudden conclusion to which an evaluator arrives. Such a conclusion is never too carefully thought out, nor is it considered totally reliable. It is an "unstable" evaluation, a provisional conclusion or an intermediate "stopover" where the evaluator pauses for a while, before starting again his/her stream of thoughts. In this sense, suppose differs from both think and believe, which encode subjective but definite conclusions, which, although probably only temporary, come at the end of a complete evaluative process. (Cappelli 2007: 218)

All in all, if a speaker supposes that $[p]$ he must have some reason so that the evidential, more precisely, inferential dimension seems to be inherent in the verb. The speaker's commitment varies from low (51) to fairly high (52 and 53).

\section{Overall evaluation of the results}

The article's contribution has been to describe the evidential and epistemic meaning aspects of Spanish verbs of cognitive attitude and of Spanish modal adverbs in particular contexts. The importance of taking the context into account when analysing these linguistic elements was highlighted. The study of naturally occurring data in their context has been proven to help to determine which meaning aspects are encoded by a particular linguistic item and which one(s) may be contributed by the context.

It should have become clear that, for instance, aparentemente has certain meaning aspects that can be assumed to be encoded by the adverb, namely visual evidence and inference, while the hearsay/reported meaning is considered to be contributed by the context. If used to convey a hearsay/ reported reading, aparentemente appears with further references to information sources. This can only be discerned by going beyond the sentence level and taking the context into account. 
Analysing the use of the modal adverbs, it was on the one hand possible to differentiate between the different types of sources of information (inference, visual evidence or hearsay) - although sometimes two readings were possible - and on the other hand between higher and lower levels of commitment: Probablemente normally expresses a higher certainty that a certain state of affairs is the case than posiblemente, but both can occur in connection with the subjunctive. If so, then the certainty about the state of affairs is attenuated. Consequently, comparing the use/function of posiblemente + indicative and probablemente + subjunctive, the former expresses a relatively high possibility and the latter a lower probability, which - semantically speaking - seems to be highly similar.

Verbs of cognitive attitude were also shown to encode certain meaning aspects, while other meaning aspects were contributed by the context. One example is the use of pensar: in contrast to saber, for instance, which is said to inherently involve some sort of evidentiality, evidentiality is not a meaning aspect that is encoded by pensar. It does not inherently lexicalize any reference to specific types of evidential information. Nevertheless, it can convey an inferential reading due to contextually provided information. So the inferential reading represents a meaning aspect of pensar that is contributed by the context.

Concerning the use of the verbs of cognitive attitude, I could conclude, on the one hand, that all verbs lexicalize the cognitive attitude concerning a certain state of affairs. But this conclusion could have been drawn at the beginning of the study already. They were all shown to be sometimes used to convey an inferential reading, but they differ depending on which meaning aspects are encoded and which are contributed by the context. These verbs also vary concerning the speaker's commitment that a certain state of affairs is/was the case. That confirms that Cappelli (2007) was right to represent each verb of cognitive attitude in a separate table. As she points out, in verbs of cognitive attitude epistemic modality and evidentiality cannot be easily kept apart:

[...] the difficulty in separating the two interwoven categories must derive from the fact that the two semantic dimensions tend to co-occur and to "evoke" each other because, cognitively, they work in strict contact. Our experience of the world tells us that if one holds that something is possible, one must have some sort of evidence justifying this sort of attitude. Conversely, if one has a certain type of evidence available, one tends to epistemically evaluate all the relative states of affairs accordingly. （Cappelli 2005: 229) 


\section{References}

Aikhenvald, Alexandra Y. 2003. Evidentiality in typological perspective. In Alexandra Y. Aikhenvald, ed. Studies in evidentiality. Amsterdam \& Philadelphia: John Benjamins, 1-31.

Aikhenvald, Alexandra Y. 2004. Evidentiality. New York: Oxford University Press.

Barnes, Janet. 1984. Evidentials in the Tuyuca verb. International Journal of American Linguistics 50: 255-271.

Boas, Franz. 1947. Kwakiutl grammar, with a glossary of the suffixes. Transactions of the American Philosophical Society 37: 201-377.

Boye, Kasper. 2010. Evidence for what? Evidentiality and scope. STUF 63: 290-307.

Cappelli, Gloria. 2005. Modulating attitudes via adverbs: A cognitive-pragmatic approach to the lexicalisation of epistemological evaluation. In M. Bertuccelli Papi, ed. Studies in the semantics of lexical combinatory patterns. Pisa: Plus Pisa University Press, 213-278.

Cappelli, Gloria. 2007. "I reckon I know how Leonardo da Vinci must have felt. . ." Epistemicity, evidentiality and English verbs of cognitive attitude. Pari: Pari Publishing.

Cornillie, Bert. 2007. Evidentiality and epistemic modality in Spanish (semi-)auxiliaries: A cognitive-functional approach. Berlin \& New York: Mouton de Gruyter.

Cornillie, Bert. 2010a. On conceptual semantics and discourse functions: The case of Spanish modal adverbs in informal conversation. Review of Cognitive Linguistics 8: 300-320.

Cornillie, Bert. 2010b. An interactional approach to evidential and epistemic adverbs in Spanish conversation. In Gabriele Diewald \& Elena Smirnova, eds. Linguistic realization of evidentiality in European languages. Berlin \& New York: Mouton de Gruyter, 309-330.

Dendale, Patrick \& Liliane Tasmowski.1994. Présentation: L'évidentialité ou le marquage des sources du savoir. Langue Française. Les sources du savoir et leurs marques linguistiques 102: 3-7.

Dendale, Patrick \& Liliane Tasmowski. 2001. Introduction: Evidentiality and related notions. Journal of Pragmatics (Special issue on "Evidentiality") 33: 339348.

Diewald, Gabriele \& Elena Smirnova. 2010. Evidentiality in German: Linguistic realization and regularities in grammaticalization. Berlin \& New York: Mouton de Gruyter.

Floyd, Rick. 1997. La estructura categorial de los evidenciales en el quechua wanka. Lima: Ministerio de Educación. Instituto Lingüístico de Verano.

Foley, William A. 1986. The Papuan languages of New Guinea. Cambridge: Cambridge University Press. 
Große, Sybille. 200o. Evidencialidade no português brasileiro. In Sybille Große \& Klaus Zimmermann, eds. O português brasileiro: Pesquisas e projetos. Frankfurt am Main: Teo Ferrer de Mesquita, 409-426.

Haßler, Gerda, ed. 1997. Texte im Text: Untersuchungen zur Intertextualität und ihren sprachlichen Formen. Münster: Nodus Publikationen.

Haßler, Gerda. 1997. Texte im Text: Überlegungen zu einem textlinguistischen Problem. In Haßler, ed. 11-58.

Haßler, Gerda. 2002. Evidentiality and reported speech in Romance languages. In Tom Güldemann \& Manfred von Roncador, eds. Reported discourse: A meeting ground for different linguistic domains. Amsterdam \& Philadelphia: John Benjamins, 143-172.

Haßler, Gerda. 2004. El uso evidencial de adverbios modales. In Juan Cuartero \& Gerd Wotjak, eds. Algunos problemas especificos de la descripción sintácticosemántica. Berlin: Frank \& Timme Verlag, 229-244.

Haßler, Gerda. 2010. Epistemic modality and evidentiality and their determination on a deictic basis. In Martin G. Becker \& Eva-Maria Remberger, eds. Modality and mood in Romance: Modal interpretation, mood selection and mood alternation. Berlin \& New York: Mouton de Gruyter, 95-108.

Haverkate, Henk. 2002. The syntax, semantics and pragmatics of Spanish mood. Amsterdam \& Philadelphia: John Benjamins.

Hoye, Leo Francis. 2008. Evidentiality in discourse: A pragmatic and empirical account. In Jesús Romero-Trillo, ed. Pragmatics and corpus linguistics: A mutualistic entente. Mouton Series in Pragmatics 2. Berlin \& New York: Mouton de Gruyter, 151-174.

Kärkkäinen, Elise. 2003. Epistemic stance in English conversation. Amsterdam \& Philadelphia: John Benjamins.

Nuyts, Jan. 2001. Epistemic modality, language, and conceptualization: A cognitivepragmatic perspective. Amsterdam \& Philadelphia: John Benjamins.

Olbertz, Hella. 2007. Dizque in Mexican Spanish: The subjectification of reportative meaning. Italian Journal of Linguistics 19: 151-172.

Oswalt, Robert L. 1986. The evidential system of Kashaya. In Wallace Chafe \& Johanna Nichols, eds. Evidentiality: The linguistic coding of epistemology. New Jersey: Ablex, 29-45.

Palmer, Frank R. 1986. Mood and modality. Cambridge: Cambridge University Press.

Plungian, Vladimir A. 2001. The place of evidentiality within the universal grammatical space. Journal of Pragmatics (Special issue on "Evidentiality") 33:349-357.

Portner, Paul. 2009. Modality. New York: Oxford University Press.

Reyes, Graciela. 1996. Los procedimientos de cita: Citas encubiertas y ecos. Madrid: Arco Libros. 
Reyes, Graciela. 2002. Los procedimientos de cita: Estilo directo y estilo indirecto. Madrid: Arco Libros.

Simon-Vandenbergen, Anne-Marie \& Karin Aijmer. 2007. The semantic field of modal certainty: A corpus-based study of English adverbs. Berlin \& New York: Mouton de Gruyter.

Squartini, Mario. 2001. The internal structure of evidentiality in Romance. Studies in Language 25: 297-334.

Squartini, Mario. 2004. Disentangling evidentiality and epistemic modality in Romance. Lingua 114: 873-895.

Volkmann, Gesina. 1997. Texte im Text und Evidentialität in Crónica de una muerte anunciada von Gabriel García Márquez. In Haßler, ed. 241-263.

Volkmann, Gesina. 2005. Weltsicht und Sprache: Epistemische Relativierung am Beispiel des Spanischen. Tübingen: Gunter Narr Verlag.

Wachtmeister Bermúdez, Fernando. 2004. La categoría evidencial del castellano: metonimia y elevación del sujeto. Boletín de Lingüística 22: 3-31. http://tinyurl. com/6sr673b (accessed 2 Jan. 2012).

Wachtmeister Bermúdez, Fernando. 2005. Evidencialidad: La codificación lingüística del punto de vista. Stockholms Universitet. $\mathrm{PhD}$ dissertation. http://tinyurl. com/6u8pc25 (accessed 2 Jan. 2012).

Willett, Thomas. 1988. A cross-linguistic survey of the grammaticization of evidentiality. Studies in Language 12: 51-97.

Author's address:

University of Potsdam

Institut für Romanistik, Linguistik und

received: 24 October 2010

Angewandte Sprachwissenschaft

resubmission invited: 21 January 2011

Am Neuen Palais 10

resubmission received: 2 February 2011

14469 Potsdam

accepted: 8 April 2011

Germany

henneman@uni-potsdam.de 